\title{
INSOLVENCY OF BRAZILIAN ELECTRICITY DISTRIBUTORS: A DEA BOOTSTRAP APPROACH
}

\author{
Rodrigo Simonassi SCALZER ${ }^{\mathrm{a}, \mathrm{b}}$, Adriano RODRIGUES ${ }^{\mathrm{a}}$, \\ Marcelo Álvaro da Silva MACEDO ${ }^{c}$, Peter WANKE ${ }^{\mathrm{a}}$ \\ ${ }^{a}$ Coppead Graduate School of Business, Federal University of Rio de Janeiro, \\ Rua Paschoal Leme, 355, 21949-900, Rio de Janeiro, Brazil \\ ${ }^{b}$ Department of Accounting, Federal University of Espirito Santo: Av. Fernando Ferrari, \\ 514, 29075-910, Vitória, Brazil \\ ${ }^{c}$ Department of Accounting, Federal University of Rio de Janeiro: \\ Av. Pasteur,250, 22290-240, Rio de Janeiro, Brazil
}

Received 23 August 2016; accepted 08 April 2017

\begin{abstract}
This study investigates the financial and operational indicators that explain the insolvency of Brazilian electricity distributors, using a data envelopment analysis (DEA) bootstrap approach. The Wagner and Shimshak (2007) stepwise procedure was used to select the variables that had the greatest impact on average efficiency estimated by DEA in the construction of an inefficient frontier. Through a second stage analysis, the Simar and Wilson (2007) bootstrapped truncated regression analyzed contextual variables associated with inefficiency, and consequently with firm insolvency. The sample was composed of electricity distributors, whose financial information for the 2000-2015 period was available on the Brazilian Securities Exchange (CVM) website. The results indicated that the Actual Equivalent Frequency of Power Interruptions/Regulatory Equivalent Frequency of Power Interruptions and Overall Indebtedness were the most important indicators in explaining insolvency. The second-stage analysis showed that the inefficiencies calculated using the selected indicators are positively related to insolvency criteria used by the literature, state control, dollar and geographical location, and negatively related to the domestic inflation index. The results provide valuable information for the Brazilian electricity sector's regulatory body, which recently began to hold public hearings prior to setting up procedures for monitoring financial sustainability using financial and operational indicators.
\end{abstract}

Keywords: electricity distributors, Brazil, insolvency, DEA, stepwise selection, inefficiency.

JEL Classification: C14, C67, G18. 


\section{Introduction}

The analysis of business insolvency has become the object of an extensive field of research, due to the direct and indirect costs that this situation can generate for company stakeholders (Warner 1977; Bhabra, Yao 2011; Boguslauskas et al. 2011; Gonçalves et al. 2016; Premachandra et al. 2011). Costs can be even greater if the company is an electricity distributor (ED) that is a natural monopoly, where a cessation of its activities thus generates impacts for society as a whole (Duane 2002; Viscusi et al. 2005).

Among the various methods found in the literature, DEA (data envelopment analysis) has appeared more recently as an alternative to the better known and traditional techniques used to analyze insolvency (Cielen et al. 2004; Kao, Liu 2004; Sueyoshi 2005; Premachandra et al. 2011; Paradi et al. 2004; Wanke et al. 2015; Premachandra et al. 2009; Simak 1997; Shetty et al. 2012; Sueyoshi, Goto 2009). DEA is a non-parametric frontier technique that does not presuppose the existence of a functional form and does not require the normal distribution of the variables used (Sueyoshi 2005). Since a pre-established functional form is not needed, the use of this technique does not incur the risk of bias when having to previously define a proxy for the group of insolvent firms, as is usually the case when discriminant analysis and logistic regression techniques are employed (Balcaen, Ooghe 2006; Balcaen et al. 2011). In addition, recent studies have presented evidence that DEA was superior to discriminant analysis and logistic regression as a technique for discriminating between solvent and insolvent firms (Premachandra et al. 2009; Sueyoshi 2006; Simak 1997).

The research on insolvency that analyzes using non-parametric models such as DEA guides the present study. In the Brazilian context, recent studies include Nova (2013), Kassai (2002), Nova (2010) and Onusic et al. (2007). However, none of these studies investigated the electricity distribution sector.

ANEEL (National Electricity Regulatory Agency), the Brazilian electricity sector's regulatory agency, is currently developing a project designed to monitor the economic and financial performance of EDs using financial and operational indicators. Technical Notes $353 / 2014$ and $67 / 2016$ proposed indicators to be discussed with society through a public consultation.

Thus, this study's aim is to propose financial and operational indicators that explain the insolvency of Brazilian EDs. This is performed using DEA to estimate an inefficiency frontier (Premachandra et al. 2011; Paradi et al. 2004; Sueyoshi 2005; Cielen et al. 2004) through the selection of indicators using the stepwise procedure of Wagner and Shimshak (2007). A second stage analysis is then undertaken, relating firms' in(efficiency) scores to different contextual variables. The underlying hypothesis is that these variables are associated with levels of efficiency and, thus, also related to ED state-of-insolvency (Simar, Wilson 2007).

The motivations for this study are firstly, to analyze insolvency in the electricity sector of an important emerging economy, Brazil. Although the models of insolvency are well documented in the scientific literature, there is little evidence as to whether these models fit the electricity sector (Oh 2014). Secondly, the Brazilian electricity sector regulator cur- 
rently needs information regarding which financial and operational indicators should be used to monitor Brazilian EDs (ANEEL 2014a). Technical notes 353/2014 and 67/2016 presented ongoing discussions and showed that this theme is still being debated and requires a solution. Thirdly, the efficiency indices are regressed against contextual variables which incorporate specific characteristics of these firms. Fourthly, the analysis covered the 2000-2015 period, thus permitting the use of a broad Brazilian ED database.

This article is organized as follows: Section 1 presents a literature review. Section 2 is divided into three subsections, devoted respectively to presenting the methodological foundations for using DEA, the stepwise procedure of Wagner and Shimshak (2007) and the bootstrap truncated regression of Simar and Wilson (2007). Section 3 presents the results of the article and the respective robustness analysis in two subsections. The final section presents the article's conclusions.

\section{Literature Review}

\subsection{Risk of insolvency in Brazilian EDs}

Regulation of the Brazilian electricity distribution sector has undergone significant transformation over the past 30 years, due mainly to problems associated with the economic and financial sustainability of EDs (Burinskiene, Rudzkis 2010; Resende 2002). The following events are examples of drivers of important transformations: the privatization of many of the sector's firms in the 1990s; electricity rationing in 2001 and 2002; and more recently, the promulgation of Provisional Measure (PM) 579/2012 by Dilma Rousseff's government, which imposed restrictions on companies that wished to renew their concession contracts (Resende 2002; Costellini, Hollanda 2014).

ANEEL is currently seeking to enhance the economic and financial sustainability of the electricity distribution sector in Brazil. Public Consultation 15/2014 inaugurated discussions around the project to monitor EDs using financial and operational indicators. Technical Notes 353/2014 and 67/2016 subsequently added proposals for indicators that the regulatory body deemed important. Despite this, the theme is still being debated and analyzed by EDs, researchers and society as a whole. Seeking to contribute to the theme, Scalzer et al. (2015) used logistic regression to explain the state of insolvency of Brazilian EDs and found that Actual Equivalent Frequency of Power Interruptions/Regulatory Equivalent Frequency of Power Interruptions (Actual EFP/Regulatory EFP), Overall Liquidity, and Interest Coverage Ratio indicators were the most important in explaining insolvency in the same year, a year before and two years before the event respectively.

As provided for in Decree 8461/2015, the EDs that renewed their concession contracts in accordance with PM 579/2012 must observe the economic and financial efficiency criteria to be established by the regulator (ANEEL 2016). The distributors that fail to fulfill the parameters required for each indicator will incur progressive penalties, including the eventual loss of the concession contract. 


\subsection{DEA on insolvency analysis}

The research on insolvency analysis has a vast literature, and uses different techniques with the goal of increasing predictive and explanatory capacity (Aziz, Dar 2006). Some surveys have reviewed these different methods in order to gauge the literature's advances (Jackson, Wood 2013; Aziz, Dar 2006; Balcaen, Ooghe 2006; Ravi Kumar, Ravi 2007; Dimitras et al. 1996; Altman 1984). These studies hold that the literature's development began with Beaver (1966) and moved historically towards the multivariate dimension with the development of discriminant analysis (Altman 1968) and subsequently advancing to logistic regression models (Ohlson 1980), which had fewer statistical assumptions and were therefore more appropriate for studies in finance and economics (Dimitras et al. 1996). In the wake of computational advances, many other quantitative techniques were developed and used, despite the still preponderant use of discriminant analysis and logistic regression in recent studies (Aziz, Dar 2006; Jackson, Wood 2013; Balcaen, Ooghe 2006).

DEA is a non-parametric technique introduced in the shape of a constant returns to scale model (CCR) by Charnes et al. (1978). Based on linear programing, the technique assesses the relative efficiency of Decision Making Units (DMUs) by assigning weights to the various inputs and outputs. Initially, the CCR model did not assume that DMUs could operate at different scales until Banker et al. (1984) introduced the variable returns to scale model (BCC), thus enabling DMUs to be compared with others of the same size. From then on, the use of DEA became widespread in various fields of research (Liu et al. 2013; Atici, Ulucan 2011).

Several studies have analyzed insolvency using DEA based on financial indicators. Cielen et al. (2004) and Sueyoshi (2006) compared the use of DEA with other mathematical discrimination techniques. Smith (1990) and Fernandez-Castro and Smith (1994) used DEA with financial indicators in order that the analysis would have a greater number of dimensions and thus not be limited to merely observing a numerator and denominator. Sueyoshi and Goto (2009), Premachandra et al. (2009) and Premachandra et al. (2011) used the Charnes et al. (1985) additive model, a translation-invariant for frontier estimation that avoids the problem found in Cielen et al. (2004) which used the CCR model despite having variables with negative data in their sample. Other studies using DEA to analyze insolvency are Paradi et al. (2004), Sueyoshi (2005), Kao and Liu (2004) and Shetty et al. (2012).

Following Pastor (1997), the output-oriented BCC model is translation invariant for the use of negative inputs, while negative outputs can be used in the input-oriented model. The output-oriented BCC model is represented as follows:

$$
\max \varnothing-\varepsilon\left(\sum_{i=1}^{m} s_{i}^{-}+\sum_{r=1}^{s} s_{r}^{+}\right)
$$

Subject to the following restrictions:

$$
\begin{gathered}
\sum_{j=1}^{n} \lambda_{j} x_{i j}+s_{i}^{-}=x_{i 0} ; \\
\sum_{j=1}^{n} \lambda_{j} y_{r j}-s_{r}^{+}=\varnothing y_{r 0} ;
\end{gathered}
$$




$$
\lambda_{j} \geq 0 ; \sum_{j=1}^{n} \lambda_{j}=1,
$$

where $x_{i j}$ is the input matrix, $y_{r j}$ is the output matrix, $s_{i}^{-}$are the input slacks, $s_{r}^{+}$are the output slacks, $\lambda_{j}$ is the intensity parameter which will be calculated by the model, $\varepsilon$ is the non-Archimedean infinitesimal, and $\varnothing$ is the relative efficiency scores of DMUs. The restriction (4) defines the format of the technology with variable returns to scale. The outputoriented BCC model was adopted for this study, given that some of the database inputs have negative values, as can be observed better in Section 2.1.

\subsection{Positioning of this study}

The significant transformations recently undergone by the Brazilian electricity sector explain ANEEL's current need to obtain answers as to which indicators should be monitored in EDs (ANEEL 2014a, 2016). In addition, the analysis of insolvency using DEA brings methodological benefits that complement logistic regression and discriminant analysis techniques, mainly by using contextual variables to explain second-stage efficiencies (Banker 1993; Simar, Wilson 2007).

\section{Method}

\subsection{Methodological foundations for using DEA}

DEA has specific properties that are advantageous in the analysis of insolvency, especially in relation to discriminant analysis and logistic regression. As it is a non-parametric technique, it (a) does not need a pre-established functional form; (b) is free from assumptions regarding the distribution of variables; and (c) requires neither normality of variables nor uniformity of dispersion among groups in the variance-covariance matrix, assumptions that are difficult to fulfill in studies in the finance area (Ohlson 1980).

In addition, DEA does not need a previous criterion for defining insolvency and thus does not incur any risk of bias in the results (Balcaen et al. 2010; Balcaen, Ooghe 2006; Dimitras et al. 1996; Jackson, Wood 2013). Altman (1968) defined insolvent firms as being those that were under receivership. Beaver (1966) saw them as firms that were unable to honor their commitments when they became due. Wruck (1990) referred to them as firms with negative equity.

In order to evaluate the insolvency of EDs, the output-oriented BCC model was used to estimate an inefficiency frontier. The indicators whose highest values were associated with financial difficulties were used as outputs, while the indicators whose lowest values were associated with financial difficulties were used as inputs (Paradi et al. 2004; Premachandra et al. 2009; Simak 1997; Sueyoshi, Goto 2009; Premachandra et al. 2011). Thus, the closer the DMU gets to the inefficiency frontier, the greater its financial difficulties and the closer it is to a state of insolvency.

Despite the advantages of DEA, several studies have been performed that expose its limitations. Schmidt (1985) classified DEA as a non-statistical technique, due to its deter- 
ministic characteristic and lack of statistical rigor. Ali and Seiford (1990) and Pastor (1997) showed that some models are not translation-invariant when using inputs and outputs with negative values - an aspect that was ignored in the Cielen et al. (2004) analysis of insolvency. In addition, there is the classic difficulty of selecting input and outputs in DEA (Adler, Yazhemsky 2010; Jenkins, Anderson 2003; Kittelsen 1993; Titko et al. 2014; Wagner, Shimshak 2007).

In light of the above, several actions were taken in this study to minimize these limitations. Firstly, a bootstrap truncated regression was adopted in a second-stage analysis; this is in following with a development in the literature that uses statistical tools in DEA (Banker 1993; Simar, Wilson 2007). Secondly, the output-oriented BCC model with variable returns to scale was used so to avoid the problem of not being translation-invariant, given that some database inputs had negative values (Pastor 1997). In these cases, their respective minimum value +0.01 , was summed in order to change the sign to a positive one. Finally, the Wagner and Shimshak (2007) stepwise procedure was used to select the variables, because its results showed parsimony, in contrast to other methods based on correlation analysis (Jenkins, Anderson 2003).

\subsection{Database and selection of variables}

The sample is based on data from financial statements publicly available on the website of the Brazil's capital markets regulator, Comissão de Valores Mobiliários (CVM), covering the 2000-2015 period. Annual data for a group of 25 companies was gathered from the Comdinheiro database. The set comprised 371 observations, given that information on some of them was available only for certain years. Thus, to maximize the amount of information used, each observation of each company is analyzed independently through pooled cross sections. The information on operational indicators was obtained from Brazilian Electricity Distributor Association (ABRADEE) website. The firms were classified as EDs if (a) their corporate objects include the distribution of electricity and (b) they obtain at least $94 \%$ of their annual operating revenue from electricity distribution. Table 1 shows the characteristics of each of the 25 EDs that include some of the contextual variables used in the second stage analysis explained in Section 2.3.

Business group in Table 1 is the company that had the largest direct interest in the capital stock of the EDs. The information shows that despite the many changes in the control structure of companies over the years, the four state-owned companies have lately remained with the same controllers. 17 EDs are located in the South, Southeast or Midwest regions, which are richer because they have per capita GDP of more than 18, and encompass the companies that purchase electricity from Itaipu. The analysis of how the state and regional location attributes affect ED efficiency is presented together with other contextual variables in Section 2.3.

Table 2 presents the 15 financial and operational indicators that are treated as inputs or outputs. Given the set of 371 DMUs, the proposed variables meet the usual criteria of proportionality between the amount of DMUs, inputs and outputs in DEA (Bogetoft, Otto 2011). The proposed variables are based on indicators used by the most important international rating agencies to evaluate the electricity distribution sector, and on the indicators 
Table 1. Description of the 25 EDs composing the sample

\begin{tabular}{|c|c|c|c|}
\hline ED & State & $\begin{array}{l}\text { Regional } \\
\text { location }\end{array}$ & Business group \\
\hline AES Sul & No & 1 & AES Guaíba II (2000-2015) \\
\hline Ampla & No & 1 & $\begin{array}{l}\text { CBLC (2000), Endesa Int (2001-2002), Enersis (2003-2004), } \\
\text { Endesa Brasil (2005-2015) }\end{array}$ \\
\hline CEEE & Yes & 1 & State of Rio Grande do Sul (2000-2015) \\
\hline Celesc & Yes & 1 & State of Santa Catarina (2000-2015) \\
\hline Celg & Yes & 1 & State of Goias (2000-2015) \\
\hline Celpa & No & 0 & QMRA Participações (2000-2014), Equatorial Energia (2015) \\
\hline Celpe & No & 0 & $\begin{array}{l}\text { ADL Energy (2000), Guaraniana (2001-2005), Neoenergia } \\
(2006-2015)\end{array}$ \\
\hline Cemar & No & 0 & $\begin{array}{l}\text { Maranhão Invest. (2000-2001), Brisk Part. (2002-2006), } \\
\text { and Equatorial Energia (2007-2015) }\end{array}$ \\
\hline $\begin{array}{l}\text { Cemig } \\
\text { Distribuição }\end{array}$ & Yes & 1 & State of Minas Gerais (2000-2015) \\
\hline Coelba & No & 0 & Guaraniana (2000-2003) and Neoenergia (2004-2015) \\
\hline Coelce & No & 0 & Investluz (2000-2012) and Endesa (2013-2015) \\
\hline Cosern & No & 0 & Coelba (2000-2006) and Neoenergia (2007-2015) \\
\hline CPFL & No & 1 & $\begin{array}{l}\text { Serra da Mesa (2000-2001), VBC (2002), and CPFL Energia } \\
(2003-2015)\end{array}$ \\
\hline $\begin{array}{l}\text { CPFL } \\
\text { Piratininga }\end{array}$ & No & 1 & $\begin{array}{l}\text { Serra da Mesa (2000-2001), VBC (2002), and CPFL Energia } \\
(2003-2015)\end{array}$ \\
\hline EBE & No & 1 & Enerpaulo (2000-2002) and EDP (2003-2015) \\
\hline Elektro & No & 1 & EPC (2000-2011) and Iberdrola (2012-2015) \\
\hline Eletropaulo & No & 1 & LightGás (2000-2002), AES Elpa (2003-2015) \\
\hline Energipe & No & 0 & Energisa (2000-2015) \\
\hline Energisa MG & No & 1 & Gipar (2000-2006), Energisa (2007-2015) \\
\hline Energisa MT & No & 1 & Caiuá (2000-2007), Rede Energia (2008-2015) \\
\hline Energisa $\mathrm{PB}$ & No & 0 & Caiuá (2000-2007), Rede Energia (2008-2015) \\
\hline Enersul & No & 1 & $\begin{array}{l}\text { Magistra Part. (2000-2005), EDP (2006-2008), Rede Energia } \\
(2009-2015)\end{array}$ \\
\hline Escelsa & No & 1 & Iven (2000-2004), EDP (2005-2015) \\
\hline Light & No & 1 & $\begin{array}{l}\text { Lidil Comercial (2000-2001), EDF Int. (2002-2005), Light SA } \\
(2006-2015)\end{array}$ \\
\hline RGE & No & 1 & Serra da Mesa (2000-2001), CPFL Energia (2002-2015) \\
\hline
\end{tabular}

Note: In the Regional Location, 1 means located in the South, Southeast or Midwest regions. 0 means located in the Northeast or North regions.

used by electricity sector regulatory agencies in other countries. This study also used the indicators proposed by ANEEL (2014a, 2016) and those Scalzer et al. (2015) found to be important in explaining the insolvency of Brazilian EDs. Following the ANEEL (2014b) and ANEEL (2016) proposals, the study used the financial $\left(X_{1} a X_{9}, Y_{1}\right)$ and operational $\left(X_{10}, X_{11}, Y_{2}, Y_{3}, Y_{4}\right)$ classes of indicators. 
Table 2. List of indicators for the analysis of ED insolvency

\begin{tabular}{|c|c|c|c|c|}
\hline Variable & Name of indicator & Formula & Category & References \\
\hline$X_{1}$ & $\begin{array}{l}\text { Interest Coverage } \\
\text { Ratio - Adjusted }\end{array}$ & $($ Ebitda + FR $) / F E$ & Input & $\begin{array}{l}\text { a, b, c, d, e, } \\
\text { f, g, h }\end{array}$ \\
\hline$X_{2}$ & Operating Margin & Ebitda/NR & Input & $\mathrm{a}, \mathrm{c}, \mathrm{h}, \mathrm{i}$ \\
\hline$X_{3}$ & Own Capital Ratio & Shareholders' Equity/TA & Input & $\mathrm{c}, \mathrm{g}$ \\
\hline$X_{4}$ & Net Margin & Net Profits/NR & Input & $\mathrm{e}$ \\
\hline$X_{5}$ & Current Liquidity & CA/Current Liabilities & Input & $b, e, j$ \\
\hline$X_{6}$ & Immediate Liquidity & CCE/Current Liabilities & Input & $\mathrm{b}$ \\
\hline$X_{7}$ & Return on Assets (ROA) & Operating Profit/TA & Input & $a, e, f$ \\
\hline$X_{8}$ & Overall Liquidity & $(\mathrm{CA}+\mathrm{LTR}) / \mathrm{TL}$ & Input & $b, g$ \\
\hline$X_{9}$ & $\begin{array}{l}\text { Net Debt/EBITDA } \\
\text { Ratio - Adjusted }\end{array}$ & $($ Ebitda + CCE $) /$ Gross Debt & Input & $\mathrm{a}, \mathrm{c}, \mathrm{h}, \mathrm{i}$ \\
\hline$X_{10}$ & Variation of GWh supplied & $\left(\mathrm{GWh}_{t}-\mathrm{GWh}_{t-1}\right) / \mathrm{GWh}_{t-1}$ & Input & $\mathrm{i}$ \\
\hline$X_{11}$ & $\begin{array}{l}\text { Variation of number } \\
\text { of consumers }\end{array}$ & $\left(\mathrm{QCons}_{t}-\mathrm{Qcons}_{t-1}\right) / \mathrm{Qcons}$ & Input & $\mathrm{i}$ \\
\hline$Y_{1}$ & Overall Indebtedness & Total Debt/TA & Output & $b, d, e, g, j$ \\
\hline$Y_{2}$ & Actual EDP / Regulatory EDP & EDP/Regulatory EDP & Output & g, h \\
\hline$Y_{3}$ & Actual EFP/ Regulatory EFP & EFP/Regulatory EFP & Output & $\mathrm{g}, \mathrm{h}$ \\
\hline$Y_{4}$ & Continuity overall performance & Average of $Y_{3}$ and $Y_{2}$ & Output & $\mathrm{g}, \mathrm{h}, \mathrm{i}$ \\
\hline
\end{tabular}

Note 1: The references are: $\mathrm{a}=$ S\&P 2013, $\mathrm{b}=$ Moody's 2013, $\mathrm{c}=$ Fitch 2014, $\mathrm{d}=$ NYPSC 2014, $\mathrm{e}=$ ERCP 2001, $\mathrm{f}=\mathrm{SARI} / \mathrm{EI}$, USAID 2004, $\mathrm{g}=$ Scalzer et al. 2015, $\mathrm{h}=$ ANEEL 2014b, $\mathrm{i}=$ ANEEL 2016, $\mathrm{j}=$ OEB 2014 .

Note 2: FR = Financial Revenue, $\mathrm{FE}=$ Financial Expenditure, $\mathrm{CCE}=$ Cash and Cash Equivalents, NR = Net Revenue, $\mathrm{TA}=$ Total Assets, $\mathrm{TL}=$ Total Liabilities, $\mathrm{CA}=$ Current Assets, $\mathrm{LTR}=$ Long-Term Receivables, Ncons $=$ Number of Consumers, EDP $=$ Equivalent Duration of Power Interruption, EFP $=$ Equivalent Frequency of Power Interruption.

The indicators that needed the firms' operating cash flow (Fitch 2014; Moody's 2013; S\&P 2013) were not used because Cash Flow Statements only became mandatory in Brazil as of 2008, with the implementation of IFRS (International Financial Reporting Standards). Nevertheless, a robustness analysis was performed to ascertain any differences in results due to the adoption of IFRS in Brazil, as had occurred in other countries (Malíková, Brabec 2012; Moody's 2013). Other traditional indicators, such as Return on Shareholders' Equity (NYPSC 2014; OEB 2014; S\&P 2013) and the Financial Result/EBITDA Ratio (ANEEL 2014a) were not included because they exhibited inconsistency problems when calculated using negative denominators. Problems of this kind and other types of data inconsistency are ignored by some studies of insolvency, as can be observed in Nenide et al. (2003) and Mendes et al. (2014).

Indicators $X_{1}$ (Interest Coverage Ratio - Adjusted) and $X_{9}$ (Net Debt/ EBITDA Ratio - Adjusted) were adapted relative to their original form. In $X_{1}$, Financial Expenditure was used as a proxy for Interest on Loans due to the lack of that information. In addition, Financial Revenue was added to the numerator to reduce distortions caused by Swap opera- 
tions that had Financial Expenditure and Revenue as their counterpart. The formula of $X_{9}$ was transformed with the new indicator exhibiting a correlation of 0.83 with the original indicator, using only those cases in which inconsistency problems did not occur.

Another important issue concerns the selection of the variables to be included in the model. There is no consensus in the literature regarding the best way to select inputs and outputs (Jenkins, Anderson 2003; Premachandra et al. 2009; Wagner, Shimshak 2007). Furthermore, the selection of variables in DEA produces more unstable results than other techniques such as regression analysis (Thanassoulis 1993). Although the approach based on correlation is a common one, the literature rarely presents a criterion for determining which variable should be kept and which should be excluded from the analysis. For this reason, Jenkins and Anderson (2003) proposed a method for selecting variables based on multivariate variance retention, albeit with erratic results.

The present study uses the backward stepwise selection procedure proposed by Wagner and Shimshak (2007), which obtained consistent results using the same data as those in Jenkins and Anderson (2003), through a proposal based on the variation in the average DMU efficiency. The elimination of each input or output is simulated in steps, and the variable excluded is the one with the smallest variation in the average DMU efficiency with the restriction that at least one input and one output must remain. The analysis of each step enables comparison of the relative importance of indicators according to the elimination ordering (Wagner, Shimshak 2007). The Kolmogorov-Smirnov (KS) test was calculated for each step in order to evaluate the difference between the efficiency distribution densities, thence assess the relevance of the inclusion/exclusion of each variable (Bogetoft, Otto 2011).

In this article the stepwise selection algorithm proposed by Wagner and Shimshak (2007) was developed by the authors using R software and for the sake of brevity was omitted from this text. More details can be found in Wagner and Shimshak (2007).

\subsection{Bootstrap truncated regression}

This study uses the bootstrap truncated regression proposed by Simar and Wilson 2007, which proved to be more effective than Tobit. Through comparisons with a Monte Carlo experiment, the method obtained higher results due to reduced statistical noise. Despite this, conventional two-step approaches lack a well-defined data generating mechanism (Simar, Wilson 2007). The model tested has the following form:

$$
\varnothing_{i}=a+Z_{j} \delta+\varepsilon_{j}, j=1, \ldots, n,
$$

where $\varnothing_{i}$ are the DEA's efficiency scores, $a$ is a constant defined by the model, $Z_{j}$ is the vector of contextual variables used for each $\mathrm{DMU} j, \delta$ is the parameter estimated for each contextual variable, and $\varepsilon_{j}$ is statistical noise. The distribution of $\varepsilon_{j}$ is conditioned by the restriction $\varepsilon_{j} \geq 1-a-Z_{j} \delta$ and, following Simar and Wilson (2007), it is assumed that the distribution is normal with zero mean and unknown variance. Replacing the unobservable true dependent variable by the one estimated by DEA:

$$
\tilde{\varnothing}_{i} \approx a+Z_{j} \delta+\varepsilon_{j}, j=1, \ldots, n,
$$


where

$$
\varepsilon_{j} \sim N\left(0, \sigma_{\varepsilon}^{2}\right), \text { such that } \varepsilon_{j} \geq a-Z_{j} \delta, j=1, \ldots . n .
$$

The efficiency estimators were calculated through the maximum likelihood method given $\delta$ and $\sigma_{\varepsilon}^{2}$. Bootstrap consistent estimators were used to calculate confidence intervals for the estimates of $\delta$ and $\sigma_{\varepsilon}^{2}$ to a given significance level. The calculations of the Simar and Wilson (2007) algorithm were carried out with $\mathrm{R}$ codes and the use of the rDEA package (Simm, Besstremyannaya 2016). The algorithms used in the estimation of the parameters were deliberately omitted for the sake of brevity and can be found in Simar and Wilson (2007).

Table 3. Contextual variables proposed

\begin{tabular}{cll}
\hline$Z_{j}$ & Name of the variable & \multicolumn{1}{c}{ Criterion adopted } \\
\hline$Z_{1}$ & $\begin{array}{l}\text { Criteria for Insolvency } \\
\text { in the Literature }\end{array}$ & $\begin{array}{l}\text { Dummy = 1 for some of the following conditions: negative Equity, } \\
\text { Receivership or Intervention by ANEEL }\end{array}$ \\
\hline$Z_{2}$ & State & $\begin{array}{l}\text { Dummy = 1 for companies in which the Federal Union, States or } \\
\text { Municipalities control more than 50\% of the voting capital }\end{array}$ \\
\hline$Z_{3}$ & Dollar & Annual average of the daily closing price measured in reais (BRL) \\
\hline$Z_{4}$ & IGPM & Percentage variation of the previous year's inflation index \\
\hline$Z_{5}$ & Regional Location & $\begin{array}{l}\text { Dummy = 1 for location in the South, Southeast or Midwest } \\
\text { regions of Brazil }\end{array}$ \\
\hline$Z_{6}$ & $\begin{array}{l}\text { Price of Electricity in } \\
\text { the Spot Market }\end{array}$ & $\begin{array}{l}\text { Annual average of the Settlement Price of the Differences (PLD) } \\
\text { traded in Brazil's Electricity Commercialization Chamber }\end{array}$ \\
\hline
\end{tabular}

Table 3 presents the contextual variables that are tested to evaluate the impact on efficiencies. No multicolineartity problems were found in numerical variables $Z_{3}, Z_{4}$ and $Z_{6}$, given that the highest correlation found among them was -0.23 . Variable $Z_{1}$ represents the insolvency criteria adopted by the literature (Altman 1968; Ohlson 1980; Wruck 1990; Balcaen, Ooghe 2006). Variable $Z_{2}$ seeks to capture whether state companies are less efficient than the others (Bagdadioglu et al. 1996; Kumbhakar, Hjalmarsson 1998). $Z_{3}$ is evaluated because approximately $20 \%$ of the cost of distributors in the South, Southeast and Midwest regions is accounted for by purchases of electricity from the Itaipu power plant, which are measured in dollars (ANEEL 2015). In addition, the dollar may have a significant impact on $Y_{1}$ (Overall Indebtedness), which averaged $71 \%$ in the case of this study's sample, in line with the $72 \%$ level calculated by ANEEL (2015). $Z_{4}$ is the indicator used by ANEEL as a basis for annual tariff increases and is directly associated with ED revenues. $Z_{5}$ verifies whether geographical location in the richest regions with a per capita GDP of more than 18 generates a difference in relation to the poorest with less than 12, in addition to the fact that the richest regions are those purchase electricity from Itaipu. Finally, as Brazil's energy matrix is based on hydropower, low reservoir levels can lead to high levels of $Z_{6}$, thus increasing the short-term cost of electricity, given that this cost is passed on to consumers only in the following year. In 2015 this led ANEEL to create tariff flag mechanisms that increase or reduce electricity costs, in accordance with momentary generation conditions, to reduce this mismatch between ED expenditures and revenues. 


\section{Analysis of results}

This section is divided into two stages. 3.1 presents an analysis of the variables associated with ED insolvency through the estimation of the inefficiency frontier in the output-oriented BCC model, and by performing a bootstrap truncated regression using efficiencies as the dependent variable. In 3.2, robustness analyses are undertaken to verify the sensitivity of the stepwise selection of variables and whether the adoption of IFRS (International Financial Reporting Standards) in Brazil has had an impact on efficiencies.

\subsection{Variables that explain insolvency}

$N$ DEA models were estimated for each step, where $N$ was equal to the sum of inputs and outputs that could be eliminated. Following Wagner and Shimshak (2007), Table 4 presents the ordered result of the variable's impact on ED efficiencies. The results of the KS test for each step showed that only two indicators could alter the initial density of step 0 efficiencies to the usual significance levels. $Y_{1}$ (Overall Indebtedness) stood out the most, with an average impact on efficiencies that was 4 times greater than $Y_{3}$ (Actual EFP/Regulatory EFP).

The number of DMUs on the frontier showed that the first variables eliminated were not able to alter the efficiency frontier and, furthermore, in the case of the last eliminations the reduction in the number of DMUs occurred gradually without big leaps between the steps.

Table 4. Variable elimination using the Wagner and Shimshak (2007) backward stepwise procedure

\begin{tabular}{ccccc}
\hline Step num. & Variable excluded & Average of $\Delta \varnothing$ & DMUs on the frontier & KS test p-value \\
\hline 0 & None & - & 18 & - \\
\hline 1 & $X_{3}$ & 0.00000 & 18 & 1.000 \\
\hline 2 & $X_{4}$ & 0.00009 & 18 & 1.000 \\
\hline 3 & $Y_{4}$ & 0.00018 & 18 & 1.000 \\
\hline 4 & $X_{7}$ & 0.00060 & 18 & 1.000 \\
\hline 5 & $X_{9}$ & 0.00136 & 17 & 1.000 \\
\hline 6 & $X_{2}$ & 0.00428 & 17 & 1.000 \\
\hline 7 & $X_{5}$ & 0.00470 & 13 & 0.996 \\
\hline 8 & $X_{11}$ & 0.00618 & 12 & 0.990 \\
\hline 9 & $X_{8}$ & 0.00297 & 9 & 0.976 \\
\hline 10 & $X_{1}$ & 0.00292 & 7 & 0.880 \\
\hline 11 & $Y_{2}$ & 0.01360 & 5 & 0.830 \\
\hline 12 & $X_{6}$ & 0.01423 & 4 & 0.592 \\
\hline 13 & $X_{10}$ & 0.01491 & 4 & 0.241 \\
\hline 14 & $Y_{3}$ & 0.28223 & 2 & $0.000^{*}$ \\
\hline 15 & $Y_{1}$ & 1.12627 & 2 & $0.000^{*}$ \\
\hline
\end{tabular}

Notes: In the case of the last input (step 13) and the last output (step 15), the presented calculations showed the changes in efficiencies if they were eliminated instead of the previous input (step 12) or the previous output (step 14) respectively;

*statistically significant to the $1 \%$ level. 
Between steps 11 and 13, indicators $Y_{2}$ (Actual EDP/Regulatory EDP), $X_{6}$ (Immediate Liquidity) and $X_{10}$ (Variation in GWh supplied), altered efficiency five times more than in step 10, despite not having altered density to the usual significance levels. The most important indicators in terms of average impact on efficiencies and densities were consistent with results of Scalzer et al. (2015), who identified $Y_{3}$ (Actual EFP /Regulatory EFP) as the most important insolvency indicator in the year of the event. In addition, the ex-ante definition of insolvency based on negative Shareholders' Equity/Assets (Wruck 1990) uses an indicator that has a correlation of -0.98 with $Y_{1}$ (Overall Indebtedness), i.e., the same indicator with opposite sign.

After estimating efficiencies using $X_{10}$ (Variation in GWh supplied), $Y_{1}$ (Overall Indebtedness) and $Y_{3}$ (Actual EFP/Regulatory EFP), the Simar and Wilson (2007) bootstrap truncated regression was performed on the contextual variables; results are shown in Table 5. Despite assuming the normality of residuals, the regression generated non-parametric results, with the variables' significance therefore being analyzed through confidence intervals based on quantiles of the distributions.

The significance of $Z_{1}$ showed that the criteria used by the literature to define insolvency in studies employing logistic regression and discriminant analysis (Altman 1968; Altman, Saunders 1997; Balcaen, Ooghe 2006; Jackson, Wood 2013; Ohlson 1980; Wruck 1990) were able to capture the EDs with the lowest efficiencies in Brazil. In addition, and in line with the literature that analyses the performance of state firms in the electricity sector, Brazilian EDs that were state companies were less efficient than those in the private sector (Bagdadioglu et al. 1996; Kumbhakar, Hjalmarsson 1998).

$Z_{3}$ (Dollar) provided evidence of the probable importance of power purchases from the Itaipu plant (ANEEL 2015), a hypothesis that was corroborated by the significance of $Z_{5}$ (Regional Location), which simultaneously showed that those regions that purchase electricity from Itaipu and have the largest regional per capita GDPs, tend to underperform relative to the others. As predicted, the significance of $Z_{3}$ may also be associated with the size of $Y_{1}$ (Overall Indebtedness). Domestic inflation $Z_{4}$ demonstrated that the annual increase in tariffs granted by ANEEL was beneficial for EDs, and $Z_{6}$ 's lack of significance showed that the mismatch between expenditures and revenues due to the high price of electricity in the spot market did not have an important impact on the firms' financial situation.

Table 5. Results of the bootstrap truncated regression using pooled data

\begin{tabular}{cccccccc}
\hline & & \multicolumn{2}{c}{$\begin{array}{c}\text { Confidence interval } \\
(\alpha=1 \%)\end{array}$} & \multicolumn{2}{c}{$\begin{array}{c}\text { Confidence interval } \\
(\alpha=5 \%)\end{array}$} & \multicolumn{2}{c}{$\begin{array}{c}\text { Confidence interval } \\
(\alpha=10 \%)\end{array}$} \\
\cline { 3 - 8 } Variable & $\delta$ & $\begin{array}{c}\text { Lower } \\
\text { bound }\end{array}$ & $\begin{array}{c}\text { Upper } \\
\text { bound }\end{array}$ & $\begin{array}{c}\text { Lower } \\
\text { bound }\end{array}$ & $\begin{array}{c}\text { Upper } \\
\text { bound }\end{array}$ & $\begin{array}{c}\text { Lower } \\
\text { bound }\end{array}$ & $\begin{array}{c}\text { Upper } \\
\text { bound }\end{array}$ \\
\hline$Z_{1}$ & $-0.72^{*}$ & -1.11 & -0.47 & -0.97 & -0.51 & -0.94 & -0.54 \\
\hline$Z_{2}$ & $-0.12^{*}$ & -0.25 & 0.00 & -0.21 & -0.04 & -0.20 & -0.05 \\
\hline$Z_{3}$ & $-0.13^{*}$ & -0.22 & -0.06 & -0.20 & -0.08 & -0.19 & -0.09 \\
\hline$Z_{4}$ & $0.69^{*}$ & 0.10 & 1.29 & 0.21 & 1.18 & 0.29 & 1.09 \\
\hline$Z_{5}$ & $-0.29^{*}$ & -0.37 & -0.21 & -0.35 & -0.23 & -0.34 & -0.24 \\
\hline$Z_{6}$ & -0.02 & -0.09 & 0.05 & -0.08 & 0.03 & -0.07 & 0.02 \\
\hline Intercept & $2.39^{*}$ & 2.21 & 2.58 & 2.25 & 2.53 & 2.26 & 2.50 \\
\hline
\end{tabular}

Note: ${ }^{*}$ statistically significant to the $1 \%$ level. 


\subsection{Robustness analysis}

New simulations were performed in order to verify the sensitivity of the stepwise selection procedure presented in Section 3.1. In Table 6, sensitivity analysis I does not use variables $Y_{10}, Y_{1}$ and $Y_{3}$, which calculated the efficiencies used in the regression in Table 5. Meanwhile, sensitivity analysis II ignores $Y_{4}, Y_{8}$ and $Y_{6}$, which were found to be significant in sensitivity analysis I. The results confirmed the importance of $Y_{6}$ (Immediate Liquidity) which had already been shown in Table 4 on being eliminated in step 12, despite not having altered densities to the usual significance levels. It was also observed that, in the absence of $Y_{3}$ (Actual EFP/Regulatory EFP), indicator $Y_{4}$ (Continuity Overall Performance) was more important than $Y_{2}$ (Actual EDP/Regulatory EDP) which had been eliminated in step 11 of Table 4. As seen previously, $Y_{4}$ is the average of $Y_{2}$ and $Y_{3}$, and thus $Y_{3}$ 's information remains in $Y_{4}$. The results of sensitivity analysis I are also in line with Scalzer et al. (2015), who also found that $Y_{8}$ (Overall Liquidity) was important when analyzing insolvent EDs. The sensitivity analysis II showed that no other variable was significant in changing ED efficiencies.

Table 7 shows the results of regressions with efficiencies calculated using the 3 significant variables of sensitivity analysis I and the variables of sensitivity analysis II.

The contextual variables of sensitivity analysis I were similarly significant and with the same sign for $\delta$ as in the regression in Table 5, despite $Z_{2}$ (State) and $Z_{4}$ (IGPM) being significant at the $5 \%$ level. Sensitivity analysis II showed that the absence of indicators capable of influencing the densities of efficiencies meant that the contextual variables did not have the explanatory power seen in previous analyses.

Table 6. Variable elimination sensitivity analysis

\begin{tabular}{ccccccc}
\hline \multirow{2}{*}{$\begin{array}{c}\text { No of } \\
\text { step }\end{array}$} & \multicolumn{3}{c}{ Sensitivity analysis I } & \multicolumn{3}{c}{ Sensitivity analysis II } \\
\cline { 2 - 7 } & $\begin{array}{c}\text { Excluded } \\
\text { variable }\end{array}$ & $\begin{array}{c}\text { Average of } \\
\Delta \varnothing\end{array}$ & $\begin{array}{c}\text { KS test } \\
\text { p-value }\end{array}$ & $\begin{array}{c}\text { Excluded } \\
\text { variable }\end{array}$ & $\begin{array}{c}\text { Average of } \\
\Delta \varnothing\end{array}$ & $\begin{array}{c}\text { KS test } \\
\text { p-value }\end{array}$ \\
\hline 1 & $X_{4}$ & 0.00073 & 1.000 & $X_{7}$ & 0.0010 & 1.000 \\
\hline 2 & $X_{7}$ & 0.00085 & 1.000 & $X_{4}$ & 0.0048 & 1.000 \\
\hline 3 & $X_{3}$ & 0.00338 & 1.000 & $X_{2}$ & 0.0091 & 1.000 \\
\hline 4 & $X_{2}$ & 0.00314 & 1.000 & $X_{9}$ & 0.0212 & 1.000 \\
\hline 5 & $Y_{2}$ & 0.00816 & 1.000 & $X_{5}$ & 0.0243 & 0.996 \\
\hline 6 & $Y_{4}$ & 0.62528 & $0.000^{*}$ & $X_{1}$ & 0.0310 & 0.954 \\
\hline 7 & $X_{9}$ & 0.00847 & 0.999 & $X_{3}$ & 0.0601 & 0.715 \\
\hline 8 & $X_{5}$ & 0.02442 & 0.996 & $X_{11}$ & 0.0691 & 0.419 \\
\hline 9 & $X_{1}$ & 0.02173 & 0.775 & & & \\
\hline 10 & $X_{11}$ & 0.03333 & 0.241 & & & \\
\hline 11 & $X_{8}$ & 0.06333 & $0.088^{* * *}$ & & & \\
\hline 12 & $X_{6}$ & 0.36294 & $0.000^{*}$ & & & \\
\hline
\end{tabular}

Notes: Only 8 variables were analyzed in sensitivity analysis II as indicator $Y_{2}$ could not be eliminated (Wagner, Shimshak 2007). In sensitivity analysis I indicator $Y_{4}$ is presented in step 6 with the values that would occur if it was eliminated in instead of the penultimate output presented in step 5;

${ }^{*}$ statistically significant to the $1 \%$ level; ${ }^{* *}$ statistically significant to the $10 \%$ level. 
Table 7. Bootstrap truncated regression in the sensitivity analysis

\begin{tabular}{|c|c|c|c|c|c|c|c|}
\hline \multirow{2}{*}{ Variable } & \multirow{2}{*}{$\delta$} & \multicolumn{2}{|c|}{$\begin{array}{l}\text { Confidence interval } \\
\qquad(\alpha=1 \%)\end{array}$} & \multicolumn{2}{|c|}{$\begin{array}{l}\text { Confidence interval } \\
\qquad(\alpha=5 \%)\end{array}$} & \multicolumn{2}{|c|}{$\begin{array}{l}\text { Confidence interval } \\
(\alpha=10 \%)\end{array}$} \\
\hline & & $\begin{array}{l}\text { Lower } \\
\text { bound }\end{array}$ & $\begin{array}{l}\text { Upper } \\
\text { bound }\end{array}$ & $\begin{array}{l}\text { Lower } \\
\text { bound }\end{array}$ & $\begin{array}{l}\text { Upper } \\
\text { bound }\end{array}$ & $\begin{array}{l}\text { Lower } \\
\text { bound }\end{array}$ & $\begin{array}{l}\text { Upper } \\
\text { bound }\end{array}$ \\
\hline \multicolumn{8}{|c|}{ Sensitivity analysis I - Efficiencies calculated for $X_{8}, X_{6}$ and $Y_{4}$} \\
\hline$Z_{1}$ & $-1.91^{\star}$ & -3.63 & -0.46 & -3.29 & -0.81 & -3.00 & -0.99 \\
\hline$Z_{2}$ & $-0.61^{\star *}$ & -1.36 & 0.03 & -1.17 & -0.11 & -1.07 & -0.18 \\
\hline$Z_{3}$ & $-0.52^{*}$ & -0.98 & -0.12 & -0.85 & -0.19 & -0.80 & -0.23 \\
\hline$Z_{4}$ & $2.53^{\star *}$ & -0.92 & 6.04 & 0.00 & 5.13 & 0.46 & 4.63 \\
\hline$Z_{5}$ & $-0.81^{*}$ & -1.26 & -0.39 & -1.14 & -0.49 & -1.11 & -0.53 \\
\hline$Z_{6}$ & -0.24 & -0.61 & 0.12 & -0.55 & 0.05 & -0.50 & 0.00 \\
\hline Intercept & $5.20^{*}$ & 4.23 & 6.27 & 4.47 & 5.97 & 4.52 & 5.86 \\
\hline \multicolumn{8}{|c|}{ Sensitivity analysis II - Efficiencies calculated for all non-significant variables } \\
\hline$Z_{1}$ & $-45.23^{\star *}$ & -128.09 & 7.10 & -93.37 & -5.92 & -84.60 & -12.46 \\
\hline$Z_{2}$ & -13.38 & -107.84 & 30.12 & -52.53 & 14.42 & -52.20 & 15.31 \\
\hline$Z_{3}$ & -0.01 & -21.34 & 19.41 & -11.39 & 17.49 & -10.23 & 14.86 \\
\hline$Z_{4}$ & $61.86^{*}$ & 4.67 & 140.40 & 15.82 & 108.55 & 21.03 & 99.58 \\
\hline$Z_{5}$ & 1.34 & -19.60 & 28.29 & -16.83 & 16.46 & -20.39 & 9.61 \\
\hline$Z_{6}$ & 0.67 & -21.21 & 16.70 & -10.11 & 15.18 & -9.86 & 14.54 \\
\hline Intercept & -18.49 & -96.10 & 45.77 & -94.12 & 23.19 & -75.41 & 9.12 \\
\hline
\end{tabular}

Notes: ${ }^{*}$ statistically significant at the $1 \%$ level; ${ }^{*}$ statistically significant at the $5 \%$ level.

a)

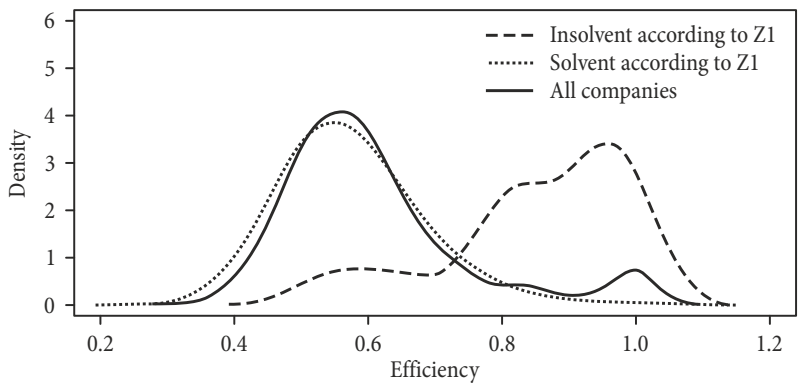

b)

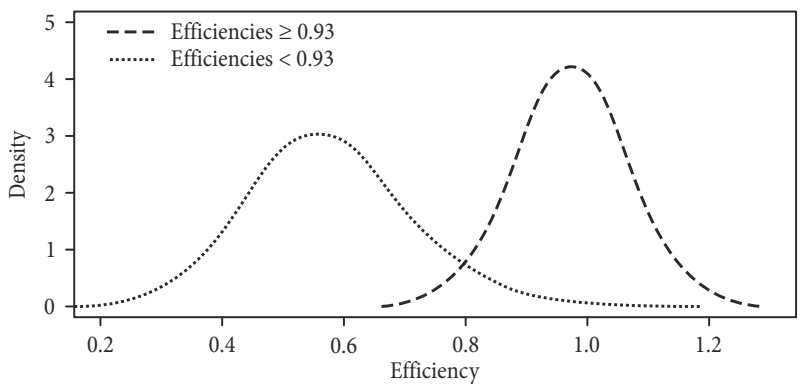

Fig. 1. Density comparisons between solvent and insolvent companies. Figure 1(a) shows the densities of the efficiencies according to $Z_{1}$ criteria, while Figure 1(b) show the densities according to the cutoff point of 0.93 . 
In addition, the analysis of the ROC (Receiver Operating Characteristic) curve was performed dividing the DMUs into two groups of solvent and insolvent firms, according to $Z_{1}$ 's insolvency criteria. The efficiencies that were treated as a dependent variable in the Table 5 regression were used as probabilities for classification in each group. The area below the ROC curve was equal to $92.72 \%$ and significantly different from $50 \%$ with a p-value 0 , thus demonstrating a high discrimination capacity. The maximum overall efficiency of $97.3 \%$ was obtained with a cutoff of 0.93 , showing a high concentration of insolvent firms among the DMUs closest to the inefficiency frontier. This was also confirmed when comparing the densities presented in Figures $1 \mathrm{a}$ and $1 \mathrm{~b}$.

Finally, in order to analyze the impact of IFRS on the results in Table 4, new simulations were performed dividing the DMUs into two groups - "up to 2009" and "as from 2010", according to Table 8. Although international accounting rules began to be adopted in Brazil in 2008, the great majority of rules were only applied from 2010 onwards, including concession accounting rules IFRIC 12 (ANEEL 2014a). Both before and after the adoption of IFRS, indicators $Y_{3}$ and $Y_{1}$ were the most important and significant in terms of altering densities, in agreement with the Table 4 results.

Table 8. Comparison of the stepwise selection before and after the adoption of full IFRS in Brazil

\begin{tabular}{ccccccc}
\hline $\begin{array}{c}\text { No }^{*} \text { of } \\
\text { step }\end{array}$ & \multicolumn{2}{c}{ Stepwise selection using data up to 2009 } & \multicolumn{3}{c}{ Stepwise selection using data as from 2010 } \\
\cline { 2 - 7 } & $\begin{array}{c}\text { Excluded } \\
\text { variable }\end{array}$ & $\begin{array}{c}\text { Average of } \\
\Delta \varnothing\end{array}$ & $\begin{array}{c}\text { KS test } \\
\text { p-value }\end{array}$ & $\begin{array}{c}\text { Excluded } \\
\text { variable }\end{array}$ & $\begin{array}{c}\text { Average of } \\
\Delta \varnothing\end{array}$ & $\begin{array}{c}\text { KS test } \\
\text { p-value }\end{array}$ \\
\hline 1 & $X_{3}$ & 0.0000 & 1.000 & $X_{9}$ & 0.0000 & 1.000 \\
\hline 2 & $Y_{4}$ & 0.0001 & 1.000 & $X_{3}$ & 0.0000 & 1.000 \\
\hline 3 & $X_{4}$ & 0.0001 & 1.000 & $X_{4}$ & 0.0000 & 1.000 \\
\hline 4 & $X_{9}$ & 0.0005 & 1.000 & $X_{7}$ & 0.0000 & 1.000 \\
\hline 5 & $X_{2}$ & 0.0018 & 1.000 & $Y_{4}$ & 0.0000 & 1.000 \\
\hline 6 & $X_{5}$ & 0.0062 & 0.998 & $X_{2}$ & 0.0000 & 1.000 \\
\hline 7 & $X_{11}$ & 0.0085 & 0.994 & $X_{8}$ & 0.0005 & 1.000 \\
\hline 8 & $X_{8}$ & 0.0032 & 0.994 & $X_{6}$ & 0.0021 & 1.000 \\
\hline 9 & $X_{1}$ & 0.0033 & 0.980 & $X_{10}$ & 0.0068 & 1.000 \\
\hline 10 & $X_{10}$ & 0.0142 & 0.704 & $X_{1}$ & 0.0073 & 0.999 \\
\hline 11 & $X_{7}$ & 0.0146 & 0.547 & $X_{5}$ & 0.0144 & 0.941 \\
\hline 12 & $X_{6}$ & 0.0228 & 0.341 & $X_{11}$ & 0.0169 & 0.794 \\
\hline 13 & $Y_{2}$ & 0.0213 & 0.158 & $Y_{2}$ & 0.0161 & 0.600 \\
\hline 14 & $Y_{3}$ & 0.3402 & $0.000^{*}$ & $Y_{3}$ & 0.0872 & $0.000^{*}$ \\
\hline 15 & $Y_{1}$ & 0.6820 & $0.000^{*}$ & $Y_{1}$ & 0.8006 & $0.000^{*}$ \\
\hline
\end{tabular}

Note: ${ }^{*}$ means that it is statistically significant to the $1 \%$ level.

\section{Conclusions}

This study brought contributions to the analysis of Brazilian ED insolvency, with the construction of an inefficiency frontier using the Wagner and Shimshak (2007) variable selection criteria accompanied by the Simar and Wilson (2007) bootstrap truncated regression. 
$Y_{1}$ (Overall Indebtedness) and $Y_{3}$ (Actual EFP/Regulatory EFP) were the most important indicators, in line with Scalzer et al. (2015). The identification of $Y_{3}$ confirms that insolvent EDs may develop operational problems and reaffirms the need to analyze issues other than financial ones (Moody's 2013; ERCP 2001).

Because of the demands presented by ANEEL in the implementation of a new regulation that monitors financial and operational indicators of EDs (ANEEL 2014a, 2016), the results of this study yielded information that can ensure better average levels of efficiencies across all EDs. Monitoring of General Indebtedness levels can anticipate problems of high levels of leverage that undermine corporate cash management and generate short-term financial distress. In addition, the monitoring of Actual EFP/Regulatory EFP is a good indicator of identification of problems in the delivery of the final service of the companies, with the increase in the interruptions in the power supply that can be associated with low levels of investment in CAPEX, high levels of indebtedness, or other types of financial distress.

The results showed that despite the risk of bias incurred by studies that used logistic regression and discriminant analysis (Balcaen, Ooghe 2006; Dimitras et al. 1996), these criteria were able to capture the EDs with the lowest efficiencies in Brazil. Moreover, state firms were more likely to be insolvent. In Brazil, public policies are usually inefficient (Burinskiene, Rudzkis 2010; Costellini, Hollanda 2014); for example, Eletrobras sold electricity in 2014 at $28 \mathrm{BRL} / \mathrm{MWH}$ while the free market price was around $822 \mathrm{BRL} / \mathrm{MWH}$. The significance of $Z_{3}$ (Dollar) and $Z_{5}$ (Regional Location) shows that the cost involved in purchasing electricity from the Itaipu plant in US dollars may affect EDs located in the South, Southeast and Midwest regions (ANEEL 2015). Tariff increases based on inflation have been beneficial, perhaps due to Brazil's high level of inflation, coupled with the high leverage levels of EDs and the low interest rates used by the National Economic and Social Development Bank (BNDES). Meanwhile, the fact that $Z_{6}$ (Spot Market Electricity Price) was not significant assumes that a shortfall in contracted electric power in the short term is not a relevant problem and may be due to the high working capital in this sector.

The robustness analysis showed that indicators that were significant in the change of efficiency densities held their coherence in the results of the Simar and Wilson (2007) regressions. In addition, the impacts of IFRS on financial statements (Malíková, Brabec 2012; Moody's 2013) did not alter the selection of the most important indicators.

The conclusions provide actionable information vis-à-vis Brazil's energy regulator (ANEEL 2014a, 2016), and make a valuable contribution to the scant literature on insolvency in the electricity sector (Scalzer et al. 2015). Future studies could test other non-parametric models that are translation-invariant, which is fundamental in insolvency studies (Sueyoshi, Goto 2009). Thus, the RAM (Cooper et al. 1999) or even the additive model (Charnes et al. 1985), which, though not having a measure for technical efficiency, is translationinvariant to the frontier (Premachandra et al. 2009, 2011). In addition, other variables such as CAPEX and Operational Cash Flow could be tested, as well as others that do not involve the financial or operational dimensions, such as the business group to which the ED belongs. 


\section{References}

ABRADEE. 2016. Setor de Distribuição [online], [cited 7 July 2016]. Associação Brasileira de Disitribuidoras de Energia Elétrica. Available from Internet: http://abradee.org.br/setor-de-distribuicao/ banco-de-dados/banco-de-dados

Adler, N.; Yazhemsky, E. 2010. Improving discrimination in data envelopment analysis: PCA-DEA or variable reduction, European Journal of Operational Research 202(1): 273-284. https://doi.org/10.1016/j.ejor.2009.03.050

Ali, A. I.; Seiford, L. M. 1990. Translation invariance in data envelopment analysis, Operations Research Letters 9(6): 403-405. https://doi.org/10.1016/0167-6377(90)90061-9

Altman, E. I. 1968. Financial Ratios, Discriminant analysis and the prediction of corporate bankruptcy, The Journal of Finance 23(4): 589-609. https://doi.org/10.2307/2978933

Altman, E. I. 1984. The success of business failure prediction models, Journal of Banking \& Finance 8(2): 171-198. https://doi.org/10.1016/0378-4266(84)90003-7

Altman, E. I.; Saunders, A. 1997. Credit risk measurement: developments over the last 20 years, Journal of Banking \& Finance 21(11-12): 1721-1742. https://doi.org/10.1016/S0378-4266(97)00036-8

ANEEL. 2014a. Nota Técnica n.353 [online], [cited 7 July 2016]. Agência Nacional de Energia Elétrica. Available from Internet: http://www.aneel.gov.br/aplicacoes/consulta_publica/documentos/NT_Indicadores\%20de\%20Sustentabilidade.pdf

ANEEL. 2014b. Consulta Pública n.15 [online], [cited 7 July 2016]. Agência Nacional de Energia Elétrica. Available from Internet: http://www2.aneel.gov.br/aplicacoes/consulta_publica/detalhes_consulta.cfm? IdConsultaPublica $=266$

ANEEL. 2015. Metodologia de Custos Operacionais [online], [cited 7 July 2016]. Agência Nacional de Energia Elétrica. Available from Internet: http://www.aneel.gov.br/aplicacoes/audiencia/arquivo/2014/023/resultado/nota_tecnica_custos_operacionais.pdf

ANEEL. 2016. Nota Técnica n.67 [online], [cited 7 July 2016]. Agência Nacional de Energia Elétrica. Available from Internet: http://www2.aneel.gov.br/aplicacoes/consulta_publica/documentos/ Nota\%20Técnica\%202016\%20067.pdf

Atici, K. B.; Ulucan, A. 2011. A multiple criteria energy decision support system, Technological and Economic Development of Economy 17(2): 219-245. https://doi.org/10.3846/20294913.2011.580563

Aziz, M. A.; Dar, H. A. 2006. Predicting corporate bankruptcy: where we stand?, Corporate Governance: The International Journal of Business in Society 6(1): 18-33. https://doi.org/10.1108/14720700610649436

Bagdadioglu, N.; Waddams Price, C. M.; Weyman-Jones, T. G. 1996. Efficiency and ownership in electricity distribution: a non-parametric model of the Turkish experience, Energy Economics 18(1-2): 1-23. https://doi.org/10.1016/0140-9883(95)00042-9

Balcaen, S.; Manigart, S.; Buyze, J.; Ooghe, H. 2011. Firm exit after distress: differentiating between bankruptcy, voluntary liquidation and M\&A, Small Business Economics 39(4): 949-975. https://doi.org/10.1007/s11187-011-9342-7

Balcaen, S.; Manigart, S.; Ooghe, H. 2010. From distress to exit: determinants of the time to exit, Journal of Evolutionary Economics 21(3): 407-446. https://doi.org/10.1007/s00191-010-0192-2

Balcaen, S.; Ooghe, H. 2006. 35 years of studies on business failure: an overview of the classic statistical methodologies and their related problems, The British Accounting Review 38(1): 63-93. https://doi.org/10.1016/j.bar.2005.09.001

Banker, R. D. 1993. Maximum likelihood, consistency and data envelopment analysis: a statistical foundation, Management Science 39(10): 1265-1273. https://doi.org/10.1287/mnsc.39.10.1265 
Banker, R. D.; Charnes, A.; Cooper, W. W. 1984. Some models for estimating technical and scale inefficiencies in data envelopment analysis, Management Science 30(9): 1078-1092. https://doi.org/10.1287/mnsc.30.9.1078

Beaver, W. H. 1966. Financial ratios as predictors of failure, Journal of Accounting Research 4(1): 71-111. https://doi.org/10.2307/2490171

Bhabra, G. S.; Yao, Y. 2011. Is bankruptcy costly? Recent evidence on the magnitude and determinants of indirect bankruptcy costs, Journal of Applied Finance and Banking 1(2): 39-68.

Bogetoft, P.; Otto, L. 2011. Benchmarking with DEA, SFA, and R. 1th ed. New York: Springer. https://doi.org/10.1007/978-1-4419-7961-2

Boguslauskas, V.; Mileris, R.; Adlyte, R. 2011. New internal rating approach for credit risk assessment, Technological and Economic Development of Economy 17(2): 369-381. https://doi.org/10.3846/20294913.2011.583721

Brazilian Securities Exchange. 2016. [online], [cited 7 July 2016]. Comissão de Valores Mobiliários. Available from Internet: http://www.cvm.gov.br/menu/regulados/companhias/companhias.html

Burinskiene, M.; Rudzkis, P. 2010. Feasibility of the liberal electricity market under conditions of a small and imperfect market. The case of Lithuania, Technological and Economic Development of Economy 16(3): 555-566. https://doi.org/10.3846/tede.2010.34

Charnes, A.; Cooper, W. W.; Golany, B.; Seiford, L.; Stutz, J. 1985. Foundations of data envelopment analysis for Pareto-Koopmans efficient empirical production functions, Journal of Econometrics 30(1-2): 91-107. https://doi.org/10.1016/0304-4076(85)90133-2

Charnes, A.; Cooper, W. W.; Rhodes, E. 1978. Measuring the efficiency of decision making units, European Journal of Operational Research 2(6): 429-444. https://doi.org/10.1016/0377-2217(78)90138-8

Cielen, A.; Peeters, L.; Vanhoof, K. 2004. Bankruptcy prediction using a data envelopment analysis, European Journal of Operational Research 154(2): 526-532.

https://doi.org/10.1016/S0377-2217(03)00186-3

Comdinheiro database. 2016. [online], [cited 7 July 2016]. Available from Internet: https://www.comdinheiro.com.br/home2/

Cooper, W. W.; Park, K. S.; Pastor, J. T. 1999. RAM: a range adjusted measure of inefficiency for use with additive models, and relations to other models and measures in DEA, Journal of Productivity Analysis 11(1): 5-42. https://doi.org/10.1023/A:1007701304281

Costellini, C.; Hollanda, L. 2014. Setor Elétrico: da MP 579 ao Pacote Financeiro [online], [cited 7 July 2016]. Available from Internet: http://fgvenergia.fgv.br/artigos/setor-eletrico-da-mp-579-ao-pacotefinanceiro

Decree 8461:2015. Regulates the Extension of Electricity Distribution Concessions. Brazilian Standard.

Dimitras, A. I.; Zanakis, S. H.; Zopounidis, C. 1996. A survey of business failures with an emphasis on prediction methods and industrial applications, European Journal of Operational Research 90(3): 487-513. https://doi.org/10.1016/0377-2217(95)00070-4

Duane, T. P. 2002. Regulation's rationale: learning from the California energy crisis, Yale Journal on Regulation 19(2): 471-540.

ERCP. 2001. Financial Capability Standards for the Restructured Philippine Electric Power Industry [online], [cited 7 July 2016]. Energy Regulatory Commission of Philippine. Available from Internet: http://pdf.usaid.gov/pdf_docs/PNADG892.pdf

Fernandez-Castro, A.; Smith, P. 1994. Towards a general non-parametric model of corporate performance, Omega 22(3): 237-249. https://doi.org/10.1016/0305-0483(94)90037-X

Fitch. 2014. U.S. Public Power Rating Criteria [online], [cited 7 July 2016]. Fitch Ratings. Available from Internet: https://www.fitchratings.com/jsp/general/Research.faces;jsessionid=iPJpqagZff095xeRuO b9HI6?listingName=criteriaReport 
Gonçalves, T. S. H.; Ferreira, F. A. F.; Jalali, M. S.; Meidutė-Kavaliauskienė, I. 2016. An idiosyncratic decision support system for credit risk analysis of small and medium-sized enterprises, Technological and Economic Development of Economy 22(4): 598-616.

https://doi.org/10.3846/20294913.2015.1074125

Jackson, R. H. G.; Wood, A. 2013. The performance of insolvency prediction and credit risk models in the UK: a comparative study, The British Accounting Review 45(3): 183-202.

https://doi.org/10.1016/j.bar.2013.06.009

Jenkins, L.; Anderson, M. 2003. A multivariate statistical approach to reducing the number of variables in data envelopment analysis, European Journal of Operational Research 147(1): 51-61. https://doi.org/10.1016/S0377-2217(02)00243-6

Kao, C.; Liu, S. 2004. Predicting bank performance with financial forecasts: a case of Taiwan commercial banks, Journal of Banking \& Finance 28(10): 2353-2368. https://doi.org/10.1016/j.jbankfin.2003.09.008

Kassai, S. 2002. Utilização da análise por envoltória de dados (DEA) na análise de demonstrações contábeis: $\mathrm{PhD}$ thesis. University of São Paulo, Brazil.

Kittelsen, S. A. C. 1993. Stepwise DEA: choosing variables for measuring technical efficiency in norwegian electricity distribution. Memorandum 06/1993. Oslo University, Norway.

Kumbhakar, S. C.; Hjalmarsson, L. 1998. Relative performance of public and private ownership under yardstick competition: electricity retail distribution, European Economic Review 42(1): 97-122. https://doi.org/10.1016/S0014-2921(96)00052-9

Liu, J. S.; Lu, L. Y. Y.; Lu, W.; Lin, B. J. Y. 2013. Data envelopment analysis 1978-2010: A citation-based literature survey, Omega 41(1): 3-15. https://doi.org/10.1016/j.omega.2010.12.006

Malíková, O.; Brabec, Z. 2012. The influence of a different accounting system on informative value of selected financial ratios, Technological and Economic Development of Economy 18(1): 149-163. https://doi.org/10.3846/20294913.2012.661193

Mendes, A.; Cardoso, R. L.; Mário, P. C.; Martinez, A. L.; Ferreira, F. R. 2014. Insolvency prediction in the presence of data inconsistencies, Intelligent Systems in Accounting, Finance and Management 21(3): 155-167. https://doi.org/10.1002/isaf.1352

Moody's. 2013. Regulated Electric and Gas Utilities [online], [cited 7 July 2016]. Moody's Investors Service. Available from Internet: https://www.moodys.com/research/Moodys-publishes-revisedmethodology-for-Regulated-Electric-and-Gas-Utilities--PR_289882

Nenide, B.; Pricer, R. W.; Camp, M. S. 2003. The use of financial ratios for research: problems associated with and recommendations for using large databases, in Fourth Annual Conference of the National Business and Economics Society, 5-8 March 2003, St. Thomas, U.S. Virgin Islands.

Nova, S. P. C. 2010. Bons em ser ruins: a utilização da análise por envoltória de dados (DEA) em modelos de análise de inadimplência/insolvência de empresas, in XXXIV Encontro da ANPAD, 25-29 Setembro 2010, Rio de Janeiro, Brasil.

Nova, S. P. C. 2013. Quanto pior, melhor: estudo da utilização da análise por envoltória de dados em modelos de análise de inadimplência/insolvência de empresas, Revista Contemporânea de Contabilidade 10(19): 71-96. https://doi.org/10.5007/2175-8069.2013v10n19p71

NYPSC. 2014. Five Year Book Index of Files - 2014 [online], [cited 7 July 2016]. New York Public Service Commission. Available from Internet: http://www3.dps.ny.gov/W/PSCWeb.nsf/All/9CBDFD5CFB 8664AF85257F630061C8F1?OpenDocument

OEB. 2014. Performance Measurement for Electricity Distributors: A Scorecard Approach [online], [cited 7 July 2016]. Ontario Energy Board. Available from Internet: http://www.ontarioenergyboard.ca/ oeb/_Documents/EB-2010-0379/Report_of_the_Board_Scorecard_20140305.pdf

Oh, N. 2014. Financial distress prediction models for wind energy SMEs, International Journal of Contents 10(4): 75-82. https://doi.org/10.5392/IJoC.2014.10.4.075 
Ohlson, J. A. 1980. Financial ratios and the probabilistic prediction of bankruptcy, Journal of Accounting Research 18(1): 109-131. https://doi.org/10.2307/2490395

Onusic, L. M.; Casa Nova, S. P. C.; Almeida, F. C. 2007. Modelos de previsão de insolvência utilizando a análise por envoltória de dados: aplicação a empresas brasileiras, Revista de Administração Contemporânea 11(2): 77-97. https://doi.org/10.1590/S1415-65552007000600005

Paradi, J. C.; Asmild, M.; Simak, P. C. 2004. Using DEA and worst practice DEA in credit risk evaluation, Journal of Productivity Analysis 21(2): 153-165. https://doi.org/10.1023/B:PROD.0000016870.47060.0b

Pastor, J. T. 1997. Translation invariance in data envelopment analysis: a generalization, Annals of Operations Research 73(1-4): 93-102.

Premachandra, I. M.; Bhabra, G. S.; Sueyoshi, T. 2009. DEA as a tool for bankruptcy assessment: a comparative study with logistic regression technique, European Journal of Operational Research 193(2): 412-424. https://doi.org/10.1016/j.ejor.2007.11.036

Premachandra, I. M.; Chen, Y.; Watson, J. 2011. DEA as a tool for predicting corporate failure and success: a case of bankruptcy assessment, Omega 39(6): 620-626.

https://doi.org/10.1016/j.omega.2011.01.002

Provisional Measure 579:2012. Provides for the Concessions for the Generation, Transmission and Distribution of Electric Energy, for the Reduction of Sectoral Charges and for the Tariff Modicity. Brazilian Standard.

Ravi Kumar, P.; Ravi, V. 2007. Bankruptcy prediction in banks and firms via statistical and intelligent techniques - a review, European Journal of Operational Research 180(1): 1-28. https://doi.org/10.1016/j.ejor.2006.08.043

Resende, M. 2002. Relative efficiency measurement and prospects for yardstick competition in Brazilian electricity distribution, Energy Policy 30(8): 637-647. https://doi.org/10.1016/S0301-4215(01)00132-X

SARI/EI; USAID. 2004. Performance Benchmarks for Electricity Distribution Companies in South Asia [online], [cited 7 July 2016]. South Asia Regional Initiative for Energy Integration. Available from Internet: http://pdf.usaid.gov/pdf_docs/PNADD964.pdf

S\&P. 2013. Utilities: Key Credit Factors For The Regulated Utilities Industry [online], [cited 7 July 2016]. Standard and Poors Rating Services. Available from Internet: http://www.standardandpoors. com/en_US/web/guest/article//view/type/HTML/sourceAssetId/1245361551274

Scalzer, R. S.; Rodrigues, A.; Macedo, M. Á. S. 2015. Insolvência empresarial: um estudo sobre as distribuidoras de energia elétrica brasileiras, Revista Contemporânea de Contabilidade 12(27): 27-60. https://doi.org/10.5007/2175-8069.2015v12n27p27

Schmidt, P. 1985. Frontier production functions, Econometric Reviews 4(2): 289-328. https://doi.org/10.1080/07474938608800089

Shetty, U.; Pakkala, T. P. M.; Mallikarjunappa, T. 2012. A modified directional distance formulation of DEA to assess bankruptcy: an application to IT/ITES companies in India, Expert Systems with Applications 39(2): 1988-1997. https://doi.org/10.1016/j.eswa.2011.08.043

Simak, P. C. 1997. DEA based analysis of corporate failure: Master's thesis. University of Toronto, Canada.

Simar, L.; Wilson, P. W. 2007. Estimation and inference in two-stage, semi-parametric models of production processes, Journal of Econometrics 136(1): 31-64. https://doi.org/10.1016/j.jeconom.2005.07.009

Simm, J.; Besstremyannaya, G. 2016. Robust Data Envelopment Analysis (DEA) for R [online], [cited 7 July 2016]. Available from Internet: https://cran.rproject.org/web/packages/rDEA/rDEA.pdf

Smith, P. 1990. Data envelopment analysis applied to financial statements, Omega 18(2): 131-138. https://doi.org/10.1016/0305-0483(90)90060-M 
Sueyoshi, T. 2005. Financial ratio analysis of the electric power industry, Asia-Pacific Journal of Operational Research 22(3): 349-376. https://doi.org/10.1142/\$0217595905000509

Sueyoshi, T. 2006. DEA-Discriminant Analysis: methodological comparison among eight discriminant analysis approaches, European Journal of Operational Research 169(1): 247-272.

https://doi.org/10.1016/j.ejor.2004.05.025

Sueyoshi, T.; Goto, M. 2009. Methodological comparison between DEA (data envelopment analysis) and DEA-DA (discriminant analysis) from the perspective of bankruptcy assessment, European Journal of Operational Research 199(2): 561-575. https://doi.org/10.1016/j.ejor.2008.11.030

Thanassoulis, E. 1993. A comparison of regression analysis and data envelopment analysis as alternative methods for performance assessments, The Journal of the Operational Research Society 44(11): 1129-1144. https://doi.org/10.2307/2583874

Titko, J.; Stankevičienè, J.; Lāce, N. 2014. Measuring bank efficiency: DEA application, Technological and Economic Development of Economy 20(4): 739-757. https://doi.org/10.3846/20294913.2014.984255

Viscusi, W. K.; Harrington, J. E.; Vernon, J. M. 2005. Economics of regulation and antitrust. 4th ed. Cambridge: MIT Press.

Wagner, J. M.; Shimshak, D. G. 2007. Stepwise selection of variables in data envelopment analysis: procedures and managerial perspectives, European Journal of Operational Research 180(1): 57-67. https://doi.org/10.1016/j.ejor.2006.02.048

Wanke, P.; Barros, C. P.; Faria, J. R. 2015. Financial distress drivers in Brazilian banks: a dynamic slacks approach, European Journal of Operational Research 240(1): 258-268. https://doi.org/10.1016/j.ejor.2014.06.044

Warner, J. B. 1977. Bankruptcy costs: some evidence, The Journal of Finance 32(2): 337-347. https://doi.org/10.2307/2326766

Wruck, K. H. 1990. Financial distress, reorganization, and organizational efficiency, Journal of Financial Economics 27(2): 419-444. https://doi.org/10.1016/0304-405X(90)90063-6

Rodrigo Simonassi SCALZER has his PhD in Business Management at COPPEAD Graduate School of Business/ Federal University of Rio de Janeiro and is currently Professor of Accounting and Finance of Federal University of Espirito Santo. Areas of his research interest: insolvency analysis, business financial management, accounting for service concession arrangements and corporate finance.

Adriano RODRIGUES has his $\mathrm{PhD}$ in Controlling and Accounting from São Paulo University (USP). Master's Degree in Accounting from the Federal University of Rio de Janeiro (UFRJ). Professor of Accounting and Finance: COPPEAD-UFRJ (School of Business) and FACC-UFRJ (Department of Accounting). His research includes financial markets reporting, accounting in regulated industries and international financial reporting standards (IFRS).

Marcelo Álvaro da Silva MACEDO has his PhD in Industrial Engineering from COPPE/UFRJ with PostDoc in Controlling and Accounting from São Paulo University (USP). Professor of Accounting and Finance: PPGCC-UFRJ (M.Sc. \& PhD Programs in Accounting - Federal University of Rio de Janeiro). His research includes Financial Markets Reporting and Quality of Accounting Information. He has over than 100 papers published in conferences and national/international impact factor scientific journals.

Peter WANKE has his $\mathrm{PhD}$ in Industrial Engineering from Federal University of Rio de Janeiro and is currently Deputy Director of Doctoral and Research at COPPEAD Business School/UFRJ, Coordinator of a research center in logistics, infrastructure and management called CELIG, and Associate Professor at COPPEAD Business School. He has over than 60 papers published in conferences, magazines, national and international impact factor scientific journals. 